\title{
Production of corn in Serbia in the light of climate change
}

\author{
DRAGANA LATKOVIĆ - JOVAN CRNOBARAC - GORAN JAĆIMOVIĆ - \\ JELENA VISKOVIĆ \\ University of Novi Sad, Faculty of Agriculture, Novi Sad, Serbia \\ dragana@polj.uns.ac.rs
}

\begin{abstract}
Summary
This paper presents the basic elements of maize production technology in Serbia. For their good knowledge, it is necessary to be familiar with the basic biological requirements of the species, phenology and its particular requirements for water, heat, soil conditions and mineral nutrition. A special emphasis in this paper is given to recent research by the author regarding the correction of production technology (selection of hybrids, time and density of sowing, etc.) from the aspect of knowing the weather conditions of the year to the moment of sowing and the amount and position of available nitrogen in the soil profile during the spring before sowing. In the light of predicted climate change conditions for the Republic of Serbia, the authors of this paper have proposed and appropriated adaptation measures. The general conclusion is that there are no general recipes for the correct production technology of this plant species, but should be adapted to each specific year, field and hybrid.
\end{abstract}

Keywords: corn, production technology, climate change, adaptation

\section{Introduction}

The economic significance of maize derived from the properties of the plant itself, the diversity of its use and volume of production. In addition, for agronomic practice the agrotechnical importance of maize is of particular importance - as a plant that requires intensive cultivation conditions, which are transmitted (have a prolonged effect) to the following plant species in the crop rotation (Marinković et al., 2012).

In terms of the characteristics of corn plant, first of all, it should noted its high genetic yield potential, the largest among all cereals. According to the amount of organic matter that can be given per hectare, it comes to the ranks of field plants with the largest amount of useful organic matter.

From our production practice, record yields of dry grains of $12 \mathrm{tha}^{-1}$ on larger surfaces and up to $18 \mathrm{t} \mathrm{ha}^{-1}$ on smaller surfaces and in irrigation systems are known. In addition to its high yielding potential, maize also has a high plasticity in terms of selection and creation of different hybrids according to purpose; with more or less oil and protein content; hybrids for special purpose (industrial processing), with a higher leaf mass, with 
a large number of stems for the production of green mass and silage, with higher sugar content etc. (Latković et al., 2014).

Corn is the most represented of all field and vegetable crops in Serbia. In the last ten-year period, it has grown on average about 1 million ha, with total production of grain about 6 million tons per year. The largest areas under corn are located in the Northern Province - Vojvodina, where it is grown on about 620,000 ha, with a total production of over $4,000,000$ tone. Regarding the future prospects for growing corn in Serbia, due to the large oscillations in yields by years (which can be partly attributed to global climate change), it is also necessary to work on the selection and breeding of maize in order to create more stable hybrids, more tolerant to stress conditions of the environment, especially on dry conditions (Marinković et al., 2008, 2011).

In addition to the afore mentioned economic importance of corn related to genetic potential, wide and diverse use, surface and production, its agrotechnical importance should be added in a particular growing system. The agrotechnical significance of maize originates from its large requirements in terms of processing, fertilization and care. Indeed, these great demands for cultivation conditions put him in the best possible preceding crop for different arable plants (Marinković et al., 2008). In our country, it represents a leading preceding crop for the second, in terms of surface and significance, culture - for winter wheat. The prospects for further corn production in the world, as well as in Serbia, will surely go in two directions - increasing the area and raising the level of yield per unit area (production intensification).

\section{Observed climate change in Serbia}

Climate change as a consequence of anthropogenic activities, primarily by means of increasing the concentration of greenhouse gases in the atmosphere can now be unambiguously detected and quantified through measured changes in many aspects of the climate system (Đurđević et al., 2015). Based on numerous studies, analyzes and reports, it is clear that today broad agreement exists on the far-reaching consequences if the global community fails to achieve future changes within the limits necessary for continued development of our global society (Olesen and Bindi, 2002; Trnka et al., 2011; Mihailović et al., 2014). The long-term goal of the international community is to limit the rise in mean global temperature to $2{ }^{\circ} \mathrm{C}$ above pre-industrial levels by means of significant reduction in greenhouse gas emissions. Observed climate changes lead to changes in the environmental, social and economic indicators, i.e. to changes in the overall conditions in which contemporary society lives across the globe and also in Serbia. It is believed that if further changes remain within the limits which have been determined as the goal, the 
mitigation of negative consequences will be possible through the appropriate and timely measures of adaptation to changing climatic conditions (Đurđević et al., 2015). On the other hand, in the case of continued uncontrolled rise in global temperatures and changes in other elements of the climate system, the consequences will be on a significantly higher scale, while adaptation will require additional efforts and additional financial investments, which can significantly slow down and hamper the progressive development of society. The aim of adaptation is to reduce the potential negative effects of climate change via planned change in the natural and socio-economic systems and to maintain the functioning of the system, or if possible, to improve efforts where such potential exists (Olesen et al., 2011).

During the period 1960-2012 in Serbia a significant increase in mean daily temperature was observed with an average temperature increase of $0.3{ }^{\circ} \mathrm{C}$ per decade. The dominant trend of increase was recorded for the period June-July-August, at $0.57{ }^{\circ} \mathrm{C}$ per decade (Lalić et al., 2011; Đurđević et al., 2015). After 1990, in only four years the negative anomaly of mean annual temperature was reported, and eight out of ten warmest years were recorded after the year 2000. The statistically relevant trend of precipitation was recorded at just a few meteorological stations. On the annual level, most stations showed a positive trend (17 out of 25 analyzed stations), but only two stations recorded a significant positive trend, while the other stations showed a negative trend in precipitation.

The average trend for the stations with positive values is $12.47 \mathrm{~mm}$ per decade, and the average trend for the stations with negative value trends is $-6.8 \mathrm{~mm}$ per decade. Although there are no significant trends in the quantity of precipitation in Serbia, we must emphasize the fact that Serbia has faced several serious precipitation trends since 2000. The most prominent were those recorded in 2000, 2003, 2007, 2011 and 2012.

Analysis of climate extremes also shows that in recent decades there have been significant changes in the frequency and intensity of extreme events, particularly those extreme events which are the result of high temperatures (Vučetić, 2011; Lalić et al., 2012; Lalić et al., 2014).

Concise conclusions of changes of extreme values in Serbia are (Đurđević et al., 2015):

- A significant increase of summer days on all stations with an average rate of 5 days per decade since 1960; tropical nights at most of the stations, an average of 1 day per decade; monthly maximum values of daily maximum temperatures and monthly maximum values of daily minimum temperatures at a large number of stations; duration of heat waves, on average 4 days per decade.

- An increase at most stations, but not significantly, of the length of the vegetation period, on average 4.5 days per decade. 
- A reduction at most stations, but not significantly, in the number of frosty and icy days, on average 2 days per decade for frosty days and 1 day per decade for icy days.

- An increase at the majority of stations, but statistically significant only at a few, of the indexes of strong and extreme precipitation: the number of days with an accumulation of more than $20 \mathrm{~mm}$, and accumulated precipitation exceeding the $90^{\text {th }}$ and $99^{\text {th }}$ percentile, with an average of 0.3 days per decade, $10 \mathrm{~mm}$ per decade and $6.5 \mathrm{~mm}$ per decade, respectively.

\section{Material and methods}

The studies on anthropogenic climate change performed in the last decade over Europe show consistent projections of increases in temperature and different patterns of precipitation with widespread increases in northern Europe and decreases over parts of southern and eastern Europe. In many countries and in recent years there is a tendency towards cereal grain yield stagnation and increased yield variability.

Some of these trends may have been influenced by the recent climatic changes over Europe (Olesen et al., 2011). The most negative effects were found for the continental climate in the Pannonian zone, which includes Hungary, Serbia, Bulgaria and Romania. This region will suffer from increased incidents of heat waves and droughts without possibilities for effectively shifting crop cultivation to other parts of the years.

There is no doubt that climate change will affect the quality and quantity of yields of major crops in Serbia, as well as the variability of yield which will be more pronounced each year. Plant production in the area of the Republic of Serbia mainly takes place in conditions of natural water supply and the natural variability of weather conditions during the year (except for production in protected areas), which is most frequently the main cause of high variability (instability) of yields between individual years. According to many climate change scenarios, which predict a further rise in greenhouse gas concentrations, we can expect more frequent occurrences of extreme weather conditions, drought and then reduction of the amount of summer precipitation in particular, on crop water requirements, the increased number of dry days and days with extreme temperatures in the individual sub-periods of vegetation (high spring and summer temperatures), warmer winters with a lower number of frostless days. All of the above will significantly affect the phenology and dynamics of growth and development of plants (Lalić and Mihailović, 2009; Lalić et al., 2013). In such conditions the most efficient adaptation measure would be irrigation; however, it is also the most complex of measures, which presupposes the existence of sufficient 
funds for investment in appropriate systems. Therefore, intensive studies are conducted and introduced in preventive and alternative ways in the production process to combat extreme weather conditions. Through customed agricultural techniques and the application of complex agrotechnical measures, it is possible to mitigate, though not completely exclude the negative impacts of climate change on the yield of cultivated plants.

The aim of this paper is to present the basic conditions of corn production in Serbia, the conventional production method, and in view of the mentioned climate change in Serbia, to propose measures for adaptation to future climate change.

\section{Results and discussion}

\section{Conditions for growing corn}

Corn is a plant originating from the south and has high demands on heat. Its cultivation is limited to the June isotherm of $17^{\circ} \mathrm{C}$, and in summer the average daytime temperature should not go below $19^{\circ} \mathrm{C}$, and the average night-time temperature for three summer months below $12.8{ }^{\circ} \mathrm{C}$ (Spasojević et al., 1984). The largest production area of corn is limited to the narrower belt, where the average daily temperatures are in the summer months of $22-26^{\circ} \mathrm{C}$, and the mean night-time is above $14.4{ }^{\circ} \mathrm{C}$, with a freeze period of 140-150 days. Corn is now significantly expanded in the northern regions thanks to hybrids with short vegetation. Corn requirements for heat are different in individual stages of development.

The speed of development, or passage through individual phases, is closely related to the amount of heat, with the provision of other conditions. According to studies of Stepanov (cit. Spasojević et al., 1984), the biological minimum for the flow of certain stages of development was determined. Thus, for the emergence, the biological minimum is 8 ${ }^{\circ} \mathrm{C}$, for the formation of a vegetative mass of $10^{\circ} \mathrm{C}$, for the formation of generative organs and a flowering of $12{ }^{\circ} \mathrm{C}$, and for maturation a temperature of $10{ }^{\circ} \mathrm{C}$.

In our conditions, maize sowing starts when soil temperatures reach 10-12 ${ }^{\circ} \mathrm{C}$ (Latković et al., 2013). Low temperatures in the first stages of corn development affect the slow development, weaker spawning and decay of one part of the plants. In the 3 leaves phase, the corn is relatively resistant to low temperatures and can withstand temperatures from -2 to $-3{ }^{\circ} \mathrm{C}$ with leaf damage. During this period, plants are sensitive to too high temperatures (over $20^{\circ} \mathrm{C}$ ), as well as those near the biological minimum, which adversely affect the development of corn. The growth period from the phase of 3 leaves to the tasseling phase is a period of relatively high demands on heat. At that time the temperature should be 
in the range from $15-20{ }^{\circ} \mathrm{C}$. If temperatures fall to $10-12{ }^{\circ} \mathrm{C}$ at that time, corn is less developed and prolongs the vegetation. Optimum at this stage is $20{ }^{\circ} \mathrm{C}$. According to Soviets data, optimal temperatures up to tasseling are $18-20{ }^{\circ} \mathrm{C}$, for the period of tasseling and flowering $20-22{ }^{\circ} \mathrm{C}$, and for maturation $22-23{ }^{\circ} \mathrm{C}$.

High temperatures are unfavourable for corn in the first stages of development, as well as very high temperatures in the flowering stage, when at $35{ }^{\circ} \mathrm{C}$ and dry air the pollen quickly decays. The height of optimal temperatures for the growth and development of maize in certain phenological phases depends on the provision of soil with water, especially during the intensive growth and until the end of the vegetation.

\section{Requirements of corn to water}

Corn is a plant that, in view of the great vegetative mass and the yields it produces, consumes large amounts of water per unit area, although it has a relatively small transpiration coefficient and uses water economically. According to various authors, the transpiration coefficient in maize is different and ranges from 180-270. According to Soviets data, a good yield can be achieved with $200-300 \mathrm{~mm}$ of precipitation if it is properly arranged, i.e. if it has enough moisture in the critical period. According to Kirjakov (cit. Spasojević et al., 1984), the critical period is 20 days before the appearance of the tassel and 10 days after the appearance of the tassel.

The critical period for the yield of corn is the stage of fertilization and grain filling. The high temperature and air and the soil moisture in the period prior to silking, contributes to an increased sterility of the plants.

The period between 2 and 3 weeks after silking is very important for the formation and filling of grains. The high temperature and lack of precipitation during this period may cause extinction of the grain already initiated (Hall et al., 1992; Pejić et al., 2009). Maize has good developed root and is very tolerate on drought. It is only vulnerable on drought in period from anthesis to maturity, June-July-August period. The expected more days with extreme high temperatures and lower precipitation in summer months may have very significant impact on decrease in yield (Jančić, 2016).

According to Vučić (cit. Spasojević et al., 1984), who dealing with these problems, for the conditions of Vojvodina, according to the average mean monthly temperatures for satisfying the necessary evapotranspiration, the corn requires the following quantities of precipitation: April 25-50 mm, May $75 \mathrm{~mm}$, June $90 \mathrm{~mm}$, July $100 \mathrm{~mm}$, August $95 \mathrm{~mm}$, and September $40 \mathrm{~mm}$; in total $425 \mathrm{~mm}$. These mean values are derived from the climatic conditions of Vojvodina, but they 
must be monitored in each region and for each year based on the water balance.

The basic climatic limiting factor of production in our conditions is the lack of precipitation and their poor distribution during the vegetation. In the largest part of our corn production area, an average of 150-200 mm of precipitation is missing compared to the ideal precipitation for high corn production (Marinković et al., 2011).

Production process of corn

Under the production process we mean complete measures that are applied in production in order to make better use of the production potential of hybrids and environmental conditions in order to achieve the maximum possible and economical yield. The basic elements of the maize production process are: selection of hybrids, the place of maize in the crop rotation, tillage system, fertilization system, sowing with all its aspects, care measures and harvest of crops.

\section{Selection of hybrids}

Today, a large number of domestic and foreign corn hybrids can be found on the market. In selecting hybrids, one should bear in mind the differences that exist both in terms of genetic potential, the length of vegetation, strength of the stem, resistance to drought and plant diseases and pests etc. As with most other species, the basic principle here is that a number of hybrids with different traits should be cultivated, to ensure stable yields and better organization of work, respectively, better utilization of equipment and other capacities.

Of particular importance is the convenience of hybrids for the mechanical harvesting of crops, i.e. the firmness of the stem and the position of the cob on the stem at the time of harvest. The environmental conditions are also an important element in the selection for individual hybrids, especially the amount of moisture. In any case, it is necessary to choose a several hybrids of different lengths of vegetation, in order to increase yield security in relation to different climatic conditions in certain years, in order to facilitate the organization of work and to ensure optimum agrotechnical deadlines for the crops for that corn are preceding crop.

\section{Crop rotation}

In earlier multi-field crop rotations, corn came to the first place of rotation. In maize, together with sugar beet were deepest ploughed and fertilized with manure. In the conditions of intense market and stronger specialized production, the classic rotations have lost their earlier importance. However, even more important is the proper crop rotation. 
In our conditions the most common proceeding crops for corn are small grains, sugar beet, sunflower, corn and soybeans. However, corn is often cultivated in repeated sowing, or in occasional monoculture.

The cultivation of corn in monoculture has been known since ancient times, especially on terrains. Most older data indicate that permanent cultivation of corn in monoculture results in declining yields, but in assessing these data, other agrotechnical moments must also be taken into account, primarily the way, the depth and time of the soil tillage, the amount of organic and mineral fertilizers, the protection from diseases, pests and weeds, and a selection of resistant hybrids (Latković et al., 2006, 2009, 2012). Until the massive appearance of corn rootworm (Diabrotica virgifera virgifera) corn could be successfully cultivated in monoculture, with proper and extensive fertilization with organic and mineral fertilizers. There is not a small number of farms in Vojvodina, which still reappears corn in reaped sowing, with satisfactory yields. However, even under conditions where Diabrotica does not cause major damage, monoculture corn production in normal circumstances should not be accepted as a permanent system of cultivation of corn, because that would entail monoculture and other field crops that are sensitive to repeated sowing. Given that the monoculture of corn is inevitable in some cases, it should be attempted to make it only casual, with the application of appropriate (more intensive) agrotechnology which ensures normal production.

\section{Soil tillage for corn}

The system of cultivation for corn is linked primarily for the preceding crop, then the soil and climatic conditions of growing areas (Marinković et al., 2008). If it is a tillage system behind small grains, which are the most common preceding crops to corn, then the following measures are applied: ploughing stubble, deep tillage during the summer or autumn and rough handling in autumn. If it is a previous crop that arrives late is removed, processing is carried out in a single stroke to full depth, while simultaneously mixing crop residues, if it is not being transferred crop residue from the plot. The significance ploughing stubble is reflected in the fight against weeds, preserving soil moisture, enriching the soil with organic matter, activating the soil microorganisms, and enriching the soil with easy-to-feed nutrients and in making the ploughing easier to carry out. Considering all the above mentioned advantages attributed to incorporation of stubble, with us in the main production areas of maize production is recommended to perform these measures immediately after the harvest of small grains at the depth should not be less than 15 $\mathrm{cm}$. 
The depth of primary tillage

The optimum tillage depth for corn is between 25 and $35 \mathrm{~cm}$, which is in accordance with the specific development and layout of the root system in the soil layers, since most of the root system is at a depth of up to 30 $\mathrm{cm}$. However, this very important issue should also be considered from the point of view of different soil properties, climate conditions, active nutrient status and the need for soil enrichment with plant assimilates, which means that the treatment system should be linked to the fertilization system (Birkás, 2008; Marinković et al., 2008). For example, if the soil is naturally deep and porous, and water regime and climate are favourable, then the tillage at a depth of $30 \mathrm{~cm}$ will be sufficient, but if it is a property with unfavourable physical properties, the harder permeable layers in humid climate that causing accumulation of water, it will be necessary to catch the basic treatment and layers deeper than 30 $\mathrm{cm}$. Deep soil tillage over $30 \mathrm{~cm}$ can be justified on the soil of a heavier mechanical compound that binds water well. In such cases, the purpose of deeper tillage is that the moisture accumulates in the lower layers and emphasizes the deeper development of the root system that will later be easier to resist drought.

The experiments showed that in the more humid region or irrigation conditions, and processing can be carried out according to the reduced system - only disking (1-2), using larger amount of mineral fertilizers, but nevertheless, a safer results are achieved by ploughing.

\section{Fertilization for corn}

Based on the general principles of fertilization, as well as knowledge of soil properties (fields), climatic conditions and requirements of each hybrid, approach to develop a system of fertilization. In order to achieve permanently stable and economically justified production of maize, the fertilization system must be connected with other elements of the production process, primarily with the soil tillage system, the structure of sowing, fertilizing for the preceding crop, incorporation of harvest residues and selection of hybrids. On the above mentioned data proven through the results of field experiments, we come to the norms and ratio of mineral elements fertilization of corn (Marinković et al., 2008).

Since the basic production conditions are different in individual areas, and especially soil and climatic, these are the norms and nutrient relationships different, which points us to the need for regional resolution of this problem. When it comes to the amounts of certain nutrients and their relationship, they originate primarily from the fertility level of certain types of soil and the amount of yield. Based on numerous research, in our country, NPK 1: 0.8: 0.6 ratio has been adopted, with the total amount of nutrients for high production of corn moving in the 
following limits: $\mathrm{N} 120-160 \mathrm{~kg}^{-1}, \mathrm{P}_{2} \mathrm{O}_{5}$ 100-140 kg ha-1 and $\mathrm{K}_{2} \mathrm{O}$ 80-120 $\mathrm{kg} \mathrm{ha}^{-1}$. It is understandable that the possible deviations are dependent on specific conditions both in terms of total quantities and the ratio of NPK.

More concrete an precise conclusions about maize fertilization can be performed only on the basis of soil sampling and determination of its basic agrochemical properties (fertility); and by balancing the nutrients based on the needs of plants for a certain amount of yield (Marinković et al., 2013). Today, the largest number of agricultural holdings in Vojvodina fertilizers are introduced into 2 times, under basic tillage, where the total predicted amount of phosphorus and potassium is ploughed and a smaller part of nitrogen, while the second part of nitrogen (estimated based on the $\mathrm{N}_{\text {min }}$ method) is applied before seeding. Based on our research, winter precipitation, nitrogen distribution by soil profile in spring and density of sowing dominantly influence corn yield (Marinković et al., 2008; Latković et al., 2012). When the distribution of nitrogen in the spring in the depth of the profile is not correct, that is, when a larger quantity is located in the surface layer, and the pre-crop rotation of the corn is increased (higher quantities than the optimal ones), this will affect the enhanced lushness of the plants. Also, the root system of corn plants will remain in the shallow surface layer. The enhanced lushness of plants implies a larger leaf surface, which irrationally consumes water from the winter period. In such cases, the dominant influence on yields will have vegetation precipitation, which in our agroecological conditions does not suffice. The poorly developed root system (shallow), excessive plant life (increased transpiration) and lack of precipitation during vegetation, especially in the three summer months (VI-VIII), will result in a significant reduction in yield. If the lack of precipitation is greater, the yield can be significantly reduced (as was the case in 2012). When the distribution of nitrogen by profile is correct (most of it is in layers from 60 to $120 \mathrm{~cm}$ ), then the root system descends deeper into the soil, uses water and from deeper layers, so the drought has so many adverse effects.

Recommendation to producers is that in the case of low winter precipitation, the optimal density for a particular hybrid should be reduced from 5 to $10 \%$, and if the disposition of mineral nitrogen is poor, then optimal density decreases from 10 to $20 \%$ compared to the recommended for given hybrid. With optimum winter precipitation and a good nitrogen profile over the profile, the optimal sowing density moves to the recommended hybrid. 
The sowing of maize

When it comes to corn sowing, it should be noted that in addition to seed quality, with the proper selection of hybrids for a particular area, the time of sowing and density of the assembly plays a very important and often decisive role (Latković et al., 2013). The seed should be good germination, cleanliness, not affected, with a maximum of $14 \%$ moisture. The seed should also be uniform in shape and size.

\section{Time of sowing}

It is known that as the beginning for the sowing of corn is considered a moment when the soil at the depth of the seed layer warm up to $10{ }^{\circ} \mathrm{C}$ which, with favourable humidity, allows the emergence in ten days. The calendar, this moment is different in years, and in the same year it is not the same for all the ends of a wider production area. However, for most of our production areas, it is considered that the optimal deadline for maize sowing is between April 5 and April 30. Early sowing, despite good humidity and even soil temperatures, can be risky, since there is a danger of late spring frosts that damage only cracked crop, although according to some data, corn in the initial stages of growth tolerates short-term frosts even up to $-6{ }^{\circ} \mathrm{C}$ with damage to the sheet. Later sowing under irrigation conditions is also not a recommendation, since the eventual lack of soil moisture can cause prolongation of germination and emergence, thus causing normal filling and maturation of corn grains (Latković et al., 2008).

Benefits of early sowing of maize are the following: the plants are better developed and have higher yield potential if their vegetation period, during May and June, flows at the time of increasing water content in the soil and the period of lower temperatures, corn plants melt and silk before the most critical period on the lack of water in the soil and avoid the damage from drought during that period, corn forms a longer root system that penetrates deeper into the soil at the end of June and early July, and better uses water from deeper layers, so it is easier to fight the drought if it occurs in this period, corn mature earlier, resulting in a lower content of water in the grain during harvest, which causes lower costs of grain drying and a lesser risk of disease and early autumn frosts.

Earlier harvesting allows early basic soil tillage for the next culture.

However, the disadvantages of early sowing of maize are as follows: in the case of low temperatures prolong the period from planting to emergence, the greater the chance for a more intense attack of pests and diseases, because we get prompt assembly, which often need re-sowing but may occur damage from late spring frosts (Latković et al., 2014).

Because on one farm should be planted several corn hybrids of different length of vegetation, it is necessary in the first periods of sowing 
sow hybrids longer growing season, and the following deadlines sowing maturing hybrids from FAO maturity groups. Also, maize sowing should not be done in a short period of time, but should preferably be done during the whole of April. Here first of all, we need to keep in mind the variable weather conditions at the time of sowing and maturing corn.

Successive sowing also enables successive crop production and harvesting, which significantly impacts the mitigation of undesirable "bottlenecks" and more rational use of machines (Marinković et al., 2008).

On the basis of all this, we consider that in Vojvodina and other similar areas, maize sowing can be started earlier, with $15-20 \%$ of the land in the first decade of April, in the second about $60 \%$ and in the third about $20-25 \%$.

\section{Sowing density}

Planting density is changed over the last thirty years, with a tendency to increase the number of plants per hectare. This was contributed to the emergence of new hybrids, which are submitted denser circuit primarily due to the changed architecture of the plant itself (greater strength of the lower internodes erectophile leaf position). The number of plants has increased from 35.000 to 40.000 at the beginning of the seventies, to 55,000 to 65,000 in the mid-eighties. Already today, it has hybrids for which it is recommended and a significantly thicker assembly (and up to 75,000 plants ha-1). However, it should be noted that the density of the plant depends on the hybrid, but also on the fertility of the soil and the expected amount and distribution of precipitation during corn vegetation. On fertile soils, better water capacity, as well as those areas where there is more precipitation during vegetation, sown denser and vice versa, and in in the drier areas, as well as on less fertile soil, sowing should be done less often. In the conditions of irrigation, sowing structure is also done densely.

\section{Conclusions}

The impact of adaptation measures in agricultural production, which belong to the cultural practices and changes in cultivation technology is specific to certain regions and crops, and also depends on the time of occurrence and the intensity of the manifestation of adverse weather factors that limit the amount of yield. Particularly important for the implementation of these measures will be disseminating information about them through various forms of education, training and training of producers, whose implementation should be organized through the cooperation of the Agricultural Faculties and the Institutes, competent 
experts of the Ministry of Agriculture and advisory and expert services. Adaptation to climate change in agriculture shall primarily include the following priority actions:

Changes of plant species and assortments in the sowing structure of sowing in relation to the expected changes in the phenology of plants. Maize can be taken as an example of these measures as a basic fodder, with a huge number of hybrids of different lengths of vegetation, which in part can be replaced with sorghum for grain, which is much more tolerant to stressful environmental conditions. Standard maize hybrids that are commonly grown in our conditions can also be replaced with the earlier hybrids in order to shorten the growing season, earlier anthesis and silking (flowering) and avoidance of drought conditions in the course of the three critical summer months.

The adequate selection of assortment under the conditions of climate change, with increasing annual fluctuations in weather conditions and more frequent extremes, suggest the cultivation of a larger number of varieties/hybrids of different lengths of vegetation on each farm. In that way, in case of an extreme event, the different varieties/hybrids will be located in different phenological phases and will react differently to stressful conditions, and shall mutually compensate for losses in yields. It is very important that the selection of hybrids and varieties comply with the soil and climatic conditions of the habitat.

Regarding the selection of varieties and hybrids in conditions with high frequency of dry years and in small grains and row crops, genotypes with shorter vegetation have an advantage, which on average can achieve $30-40 \%$ higher yield compared to medium late and late genotypes.

Work on the selection, breeding and creation of tolerant genotypes. This adaptation measure requires a longer period of time in the selection and breeding establishments. However, the findings are invaluable and enable the creation of varieties and hybrids of cultivated species with tolerance to stressful conditions, particularly drought, or genotypes with altered phenology, length of vegetation, etc., which for example could allow the cultivation of varieties/hybrids of earlier flowering or ripening in regions with extremely dry summers in conditions without irrigation.

Adapting the basic treatment systems. One of the main goals of treatment is to improve the water regime of land or a larger accumulation and conservation of moisture in it. In well-treated soil water more easily penetrates into the deeper layers and creates greater supplies of water for dry periods. Also, ameliorative treatment of hydromorphic soils improves vertical and horizontal drainage, which reduces the risk of over-moisturizing and creation of waterlogged areas in micro depressions. Properly and timely derived treatment measures can 
significantly reduce the evaporation of water from the soil. These measures include: peeling (shallow ploughing), primary processing, surface treatment, treatment during vegetation, and conservation treatment.

Conservation tillage of soil. Change of tillage practices may be one of the most effective adaptation measures in agriculture and is already widely used in many regions of the world. This processing system may include any system that ensures that at least 30\% of the land after sowing is covered by crop residues. The presence of plant residues on the soil surface softens erosion by wind and water, while during dry conditions significantly reduce evaporation and contribute to the preservation of soil moisture.

Adequate rational fertilization. It is known that water consumption is substantially reduced in conditions of optimum and harmonious mineral nutrition. In dry conditions the process of mineralization is slowed down which leads to a reduction in the amount of available forms of assimilates in the soil. At the same time it reduces the ascendant transport of approved feedstuffs, which worsens supply of above ground organs with mineral matters.

Organic fertilization - enriching the soil with organic matter and humus in order to increase the water-air regime of soil. Regular use of manure, compost, siderate and other forms of organic matter in the soil can very effectively alleviate the impact of drought. This measure has a positive effect on the balance of humus, the activity of microorganisms, the creation of stable structural aggregates, which is reflected in a number of physical properties of the soil, primarily on its water, air and thermal regime. In arid conditions the most important role of humus formed from the decomposition of organic matter is that it can absorb large quantities of water, which increases the power of keeping readily available water and its contents, which is very important to better supply plants with water in dry periods.

Change and improvement of the treatment system with the aim of improved moisture conservation (application of reduced treatment systems). The systems of reduced and minimum treatment of soil without turning over the arable layer serves to reduce the deterioration of soil structure, humus degradation, reduction of soil compaction, improvement of water-air properties and increase of beneficial microfauna in the soil, as well as a reduction in hydro and wind erosion. These systems practically enable greater accumulation of water in the soil.

Changes in time and sowing density. Scenarios of possible future climate change enable earlier sowing and harvesting of crops, and greater participation of earlier varieties/hybrids in the sowing structure. Under the anticipated conditions of the increased trend in dry days for the 
period April-August, planting density should be reduced, especially in years with low levels of winter precipitation. Transpiration and water consumption per plant are higher in lower density crops; therefore by using the optimum density of plants, losses from evaporation can be reduced. The cause of decrease in yield in denser structures is a significantly bigger leaf area, higher transpiration and greater competition of plants for water. In dry conditions, the cultivation of maize in the denser structure can reduce the yield by $30-50 \%$, while in sandy soils with low water holding power, root crops can be completely destroyed by drought (for e.g. in 2012).

\section{References}

Birkás, M. (2008): Environmentally-sound adaptable tillage. Akadémia Kiadó Budapest. 1-354.

Đurđević, V.-Plavšić, J.-Lalić, B.-Stričević, R.-Jaćimović, G.-Firanj, A.-Orlović, S.Stojanović, D.-Radović, D.-Mladenović, A.-Stanisavljević, B.-Mitrović, Đ. (2015): „Prvi nacionalni plan adaptacije na izmenjene klimatske uslove za Republiku Srbiju" (Serbia's first national adaptation plan) - nacrt pripremljen u okviru UNDP-GEF projekta „Drugi izveštaj R. Srbije prema UNFCCC“ koji sprovodi Ministarstvo poljoprivrede i zaštite životne sredine uz tehničku podršku UNDP i finansijsku podršku GEF. Ministarstvo poljoprivrede i zaštite životne sredine, Beograd. 1-74.

Hall, A. J.-Vilella, F.-Trapani, N.-Chimenti, C. (1992): The effects of water stress and genotype on the dynamics of pollen shedding and silking in maize. Field Crops Res. 5: 349-363.

Jančić, M. (2016): Impact of climate changes on crop production. Doctoral thesis. University of Novi Sad. Faculty of Agriculture.

Jančić, M. (2013): Impact of Climate Change on Maize Yield in the Region of Novi Sad (Vojvodina). Field and Vegetable Crops Research. 50. 3: 110-114.

Lalić, B.-Mihailović, D. T. (2009): Assessment of climate change impact on phenology dynamic in Vojvodina region. $9^{\text {th }}$ Annual Meeting of the EMS $/ 8^{\text {th }}$ ECAC. Toulouse. France. 6: 504-1.

Lalić, B.-Eitzinger, J.-Mihailović, D. T.-Thaler, S.-Jančić, M. (2012): Climate change impacts on winter wheat yield change - which climatic parameters are crucial in Pannonian lowland? The Journal of Agricultural Science. 151. 6: 757-774.

Lalić, B.-Eitzinger, J.-Thaler, S.-Vučetić, V.-Nejedlik, P.-Eckersten, H.-Jaćimović, G.Nikolić-Đorić, E. (2014): Can Agrometeorological Indices of Adverse Weather Conditions Help to Improve Yield Prediction by Crop Models? Atmosphere (publisher: MDPI AG (Multidisciplinary Digital Publishing Institute). Basel. Switzerland. 5. 4: 1020-1041. 
Lalić, B.-Francia, M.-Jaćimović, G. (2013): Assessment of climate change impact on crop water requirements in Serbia in 2030 using CROPWAT model. [In: Šiška et al. (eds). Scientific proceeding.] International Scientific Conference

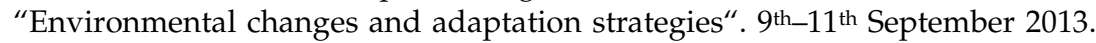
Slovak University of Agriculture in Nitra. Skalica. Slovakia. 148-151.

Lalić, B.-Mihailović, D. T.-Podraščanin, Z. (2011): Buduće stanje klime u Vojvodini i očekivani uticaj na ratarsku proizvodnju. Ratar. Povrt. 48. 2: 403-418.

Latković, D.-Jaćimović G.-Malešević M.-Marinković B.-Crnobarac, J.-Sikora, V. (2011): Effect of Fertilization System and $\mathrm{NO}_{3}-\mathrm{N}$ Distribution on Corn Yield. Cereal Res. Commun. 39. 2: 289-297.

Latković, D.-Jaćimović, G.-Malešević, M.-Marinković, B.-Crnobarac, J. (2012): Corn Monoculture Yield Response to Fertilization and Nitrate Nitrogen Distribution. Communications in Soil Science and Plant Analysis. 43. 7: 10151023.

Latković, D.-Jaćimović, G.-Marinković, B.-Malešević, M.-Crnobarac, J. (2009): Sistem đubrenja u funkciji prinosa kukuruza u monokulturi i dvopolju. Letopis naučnih radova. Poljoprivredni fakultet Novi Sad. 33. I: 77-84.

Latković, D.-Marinković, B.-Crnobarac, J.-Jaćimović, G.-Berenji, J.-Sikora, V. (2012): Influence of crop residues and increasing rates of nitrogen on the yield of corn. International Symposium "Trends in the European Agriculture Development“. May 17-18, 2012. Banat's University of Agricultoral Sciences and Veterinary Medicine, Faculty of Agriculture, Timisoara and University of Novi Sad, Faculty of Agriculture. Timisoara. Romania. Research Journal of Agricultural Science. 44. 3: 61-66.

Latković, D.-Marinković, B.-Jaćimović, G.-Crnobarac, J. (2013): Uticaj roka i gustine setve na visinu prinosa kukuruza. Tematski zbornik Naučno-stručnog savetovanja „Poruke minule godine i nova setva“. Poljoprivredni fakultet Novi Sad Departman za ratarstvo i povrtarstvo. 21-23.

Latković, D.-Marinković, B.-Jaćimović, G.-Crnobarac, J. (2014): Biološke i agrotehničke osnove proizvodnje kukuruza. Biljni lekar/Plant Doctor, Poljoprivredni fakultet Novi Sad. 42. 2-3: 109-125.

Latković, D.-Starčević, Lj.-Marinković, B.-Crnobarac, J.-Jaćimović, G. (2006): Prinos zrna i iznošenje azota pri različitom đubrenju u monokulturi kukuruza. Letopis naučnih radova. Poljoprivredni fakultet. Novi Sad. 30. 1: 134-140.

Marinković, B.-Crnobarac, J.-Bogdanović, D.-Latković, D.-Jaćimović, G. (2013): Određivanje optimalnih količina azota za đubrenje šećerne repe i kukuruza (Determining the optimal nitrogen amounts for sugar beet and maize fertilization). Knjiga izvoda iz saopštenja, Šesti naučno-stručni skup »InterRegioSci 2013«. Novi Sad. Pokrajinski sekretarijat za nauku i tehnološki razvoj. Vlada AP Vojvodine. 18.

Marinković, B.-Crnobarac, J.-Jaćimović, G.-Marinković, D. (2008): Tehnologija gajenja u funkciji optimalnog prinosa, prilagođena godini, njivi i hibridu/sorti (pregledni rad). »Zbornik radova«. Institut za ratarstvo i povrtarstvo. Novi Sad. 45. I: 159-178. 
Marinković, B.-Crnobarac, J.-Jaćimović, G.-Marinković, D.-Mircov, D. V.-Rajić, M.Imbrea, F. (2011): Climatic factors and their importance in the formation of a record corn yield. $20^{\text {th }}$ International Symposium $»$ Ecology \& Safety, For a cleaner and safer world «. June 4-8, 2011. Sunny Beach Resort. Bulgaria. Journal of International Scientific Publication: Ecology \& Safety. 5. 1: 62-68.

Marinković, B.-Crnobarac, J.-Latković, D.-Jaćimović, G. (2012): Tehnologijom gajenja NS hibrida kukuruza do optimalnih i/ili rekordnih prinosa. 46. savetovanje agronoma Srbije. Zlatibor. 29. 01-04. 02. 2012. Institut za ratarstvo i povrtarstvo Novi Sad. Zbornik referata. 239-255.

Marinković, B.-Crnobarac, J.-Malešević, M.-Jaćimović, G.-Marinković, D.-Latković, D. (2012): Racionalna upotreba đubriva u ratarskoj proizvodnji. Priručnik (dopunjeno i izmenjeno izdanje) (ed. B. Marinković), Poljoprivredni fakultet Novi Sad i Pokrajinski Sekretarijat za poljoprivredu, vodoprivredu i šumarstvo AP Vojvodine . 1-25.

Marinković, B.-Crnobarac, J.-Marinković, D.-Jaćimović, G.-Mircov, D. V. (2008): Weather conditions in the function of optimal corn yield in Serbia and the Vojvodina province. International scientific conference "1 $1^{\text {st }}$ Scientific Agronomic Days". 13-14. november 2008. Slovak University of Agriculture Nitra. Department of Crop Production. Faculty of Agrobiology and Food Resources. Slovak Republic. Proceeding of reviewed scientific papers, collection of critiqued scientific works on CD. 15-19.

Mihailović, D. T.-Lalić, B.-Drešković, N.-Mimić, G.-Djurdjević V.-Jančić, M. (2014): Impact of observed and projected shifts of Köppen climate zones on the crops yield change in Serbia under the SRES-A1B and SRES-A2. International Journal of Climatology.

Olesen, J. E.-Trnka, M.-Kersebaum, K. C.-Skjelvag, A. O.-Seguin, B.-Peltonen-Sainio, P.-Rossi, F.-Kozyra, J.-Micale, F. (2011): Impacts and adaptation of European crop production system to climate change. European Journal of Agronomy. 34: $96-112$.

Olesen, J. E.-Trnka, M.-Kersebaum , K. C.-Skjelvåg, A. O.-Seguin, B.-Peltonen-Sainio, P.-Rossi, F.-Kozyra, J.-Micale, F. (2011): Impacts and adaptation of European crop production systems to climate change. European Journal of Agronomy. 34: $96-112$.

Olesen, J. E.-Bindi, M. (2002): Consequences of climate change for European agricultural productivity, land use and policy. European Journal of Agronomy. 16: 239-262.

Pejić, B.-Bošnjak, Đ.-Mačkić, K.-Stričević, R.-Simić, D.-Drvar, A. (2009): Osetljivost kukuruza (Zea mays L.) na deficit vode u zemljištu u određenim podperiodima vegetacije. Letopis naučnih radova Poljoprivrednog fakulteta. 33. 1: 155-166.

Spasojević, B.-Stanaćev, S.-Starcević, Lj.-Marinković, B. (1984): Posebno ratarstvo I (Uvod, žita i zrnene mahunjače). Univerzitet u Novom Sadu. Poljoprivredni fakultet. OOUR Institut za ratarstvo i povrtarstvo. Novi Sad. 
Trnka, M.-Olesen, J.-Kersebaum, C.-Skjelvåg, A.-Eitzinger, J.-Seguin, B.-PeltonenSainio, P.-Iglesias, A.-Rötter, R.-Orlandini, S.-Dubrovský, M.-Hlavinka, P.-Balek, J.-Eckersten, H.-Cloppet, E.-Calanca, P.-Gobin, A.-Vučetić, V.-Nejedlik, P.Kumar, S.-Lalić, B.-Mestre, A.-Rossi, F.-Kozyra, J.-Alexandrov, V.-Semerádová, D.-Žalud, Z. (2011): Agroclimatic conditions in Europe under climate change. Global Change Biology. 17. 7: 2298-2318.

Vučetić, V. (2011): Modelling of maize production in Croatia: present and future climate. Jornal of Agricultural Science. 149. 2: 145-157. 